\title{
Physicochemical and sensory qualities of bread fortified with banana, aonla and sapota powders
}

\begin{abstract}
Bread prepared by incorporating powders of fruits (banana $-10 \%, 20 \%$; aonla $5 \%, 10 \%$; sapota $-10 \%, 20 \%$; ) at different proportions to the standard recipe were evaluated for various physico-chemical and sensory parameters. Addition of banana, sapota and aonla powder enhanced nutritional quality in terms of crude fiber and carbohydrates. Incorporation of banana, aonla and sapota powder in bread resulted in decrease in gluten, protein and total sugar content of breads from 18.33 to 11.66 per cent and 11.31 to 8.51 per cent, 6.52 to 5.03 per cent, respectively. Water activity and moisture content in breads varied from 0.77 (5\% aonla powder) to $0.82(20 \%$ banana and $20 \%$ sapota powder) and 29.16 per cent ( $10 \%$ aonla powder) to 41.00 per cent $\left(20 \%\right.$ aonla and $20 \%$ sapota powder), respectively. Colour values $\left(L^{*}, a^{*}\right.$, and $\left.b^{*}\right)$ differed from 69.46 (control) to 45.92 (20\% sapota powder), 4.4 (20\% sapota powder) to -0.68 (control), 12.11 ( $10 \%$ aonla powder) to 6.69 ( $10 \%$ banana powder) indicating greater lightness of bread made from 100 per cent refined wheat flour. Sensory analysis revealed that breads incorporated with sapota and banana powders up to 20 per cent and aonla powder up to 5 per cent did not affect the sensory qualities.
\end{abstract}

Volume 8 Issue 6 - 2018

\author{
Rajeswari H, Jagadeesh SL, Suresh GJ \\ Department of Postharvest technology, University of \\ Horticultural Sciences, India
}

\begin{abstract}
Correspondence: Suresh G], Assistant Professor, Department of Postharvest Technology, College of Horticulture, UHS Campus, GKVK Post, Bengaluru-560 065, Karnataka, India, Email suresh.gj@uhsbagelkot.edu.in
\end{abstract}

Received: April 05, 2018| Published: November 28, 2018

Keywords: bread, banana, aonla and sapota powder, chemical composition and sensory properties

\section{Practical applications}

The Bakery industry may use the flours of banana, aonla and sapota for incorporation into the bread making without much affecting the sensory qualities with improved fiber contents. This will address effective utilization of fruits when there is excess production and improving the nutrient status of people.

\section{Introduction}

Fruits are important in human diet owing to their nutritional value. They provide nutritional security in addition to food security. They supplement carbohydrates, proteins, vitamins and minerals which are essentially required for good health. They are also valued for their medicinal importance in improving digestion, reducing chronic diseases etc. As per the standard laid down by the Indian Council of Medical Research, the recommended per capita per day requirement of fruits are $100 \mathrm{~g}$. But the actual consumption of fruits accounts for $88 \mathrm{~g}$ per day per capita. ${ }^{1}$ The demand for processed food is increasing rapidly with increasing urbanization. Among the processed foods, bakery products command wide popularity. Baked products, especially bread and biscuits form an important part of Indian dietary. These products are rich in starch, fat and energy but depleted of fiber. Various epidemiological studies have shown that diet lacking in fiber may be the cause for various gastrointestinal and cardiovascular diseases. ${ }^{2}$ Bread occupies an important place in baking industry in the total Indian market for bakery products. It is consumed by majority of population all over the world as a part of daily diet and is equally popular in urban and rural regions. The production of bread in India is 9.58lakh tones and its estimated growth rate is $9.7 \%$ per annum. However, to sustain the growth, the industry needs to diversify its products. 'Functional foods' are the food components that benefit health beyond the basic nutrition. Conventional foods, fortified, enriched or enhanced foods and dietary supplements are some of the examples of functional foods. These substances provide essential nutrients often beyond quantities necessary for normal maintenance, growth, development, and other biologically active components that impart desirable physiological effects. ${ }^{4}$

Fruits are good sources of fibers, minerals and vitamins. They are cheaper and easily available but are seasonal and highly perishable. Nearly 25 per cent of fruits go waste due to their perishable nature, lack of appropriate post-harvest infrastructure and transportation, inadequate marketing set up and processing. ${ }^{5}$ Processing of fruits reduce the post-harvest losses and make them available throughout the year. ${ }^{6}$ Increasing fiber content in bakery products were studied by many researchers. Particularly, incorporation of various forms of dietary fiber (DF)in the production of bread such as pear, apple and date fibers, ${ }^{7}$ butternut fiber ${ }^{8}$ Annona crassiflora flour, ${ }^{9}$ wheat bran, oat bran, ${ }^{10}$ corn bran, ${ }^{11}$ date seed fiber, ${ }^{12}$ apple fiber, ${ }^{13}$ carob fiber, ${ }^{14}$ psyllium husk fiber, ${ }^{15}$ filed pea hull ${ }^{16}$ and hazelnut. ${ }^{17}$ To our knowledge, the use of banana, aonla and sapota powders in the bread production to increase the functionality and their effects on physicochemical qualities is less studied. In this context, utilization of substantial quantum of fruits in bakery product such as bread not only improves the food functionality of these foods but also helps in reducing the post-harvest losses of fruits. Hence, the present investigation was therefore undertaken to develop bread by incorporating banana, aonla and sapota powders and to study the physicochemical and sensory quality of bread.

\section{Materials and methods}

\section{Preparation of banana, aonla and sapota powder}

Banana (Musa paradisica) fruits harvested at mature unripe stage were peeled and sliced .Slices were subjected to sulphuring $(2 \mathrm{~g} / \mathrm{kg})$ for 30minutes in a sulphuring chamber. After sulphuring, the slices were dried in an electric dehydrator at $60^{\circ} \mathrm{C}$ temperature for 24 hours. The dried slices were ground using electric grinder and the resultant 
powder was packed air tight in aluminium foil pouch for use in the preparation of bread. Sapota (Achrus zapota) fruits procured from the orchard at mature unripe stage were allowed for 3days to ripen in the laboratory. Ripened fruits were peeled with the help of a hand peeler and the segments were separated. They were subjected to sulphuring and dried as banana slices. The sapota powder thus prepared was packed in aluminium foil pouch and sealed for use in the preparation of bread. Mature aonla (Emblica officinalis) fruits were brought from a farmer's field were washed with tap water and sliced with the help of aonla slicing machine. The fruit slices were dried in an electric drier at $60^{\circ} \mathrm{C}$ for 4 hours. The dried slices were ground to fine powder using an electric grinder. The powder was kept sealed in aluminium foil pouch for use in the preparation of bread.

\section{Preparation of Refined white flour}

Refined white flour is made from whole wheat grains by peeling off entire husk and bran then crushing the white grain, almost pure carbohydrate parts. Husk and bran are the most nutritious and fiber rich parts of the grain. The remaining part of grain is carbohydrate and not much else. Even the tiny bit of remaining nutrition in the remaining part of grain is chemically bleached out. Then it is dried in the oven Refined white flour is made from whole wheat grains by peeling off entire husk and bran then crushing the white grain, almost pure carbohydrate parts. Husk and bran are the most nutritious and fiber rich parts of the grain. The remaining part of grain is carbohydrate and not much else. Even the tiny bit of remaining nutrition in the remaining part of grain is chemically bleached out. Then it is dried in the oven at $150^{\circ} \mathrm{c}$ temperature which destroys any trace of nutrients that may remain there.

\section{Bread preparation methodology}

Standard recipe followed for preparation of bread included refined wheat flour (Maida) $1000 \mathrm{~g}$, yeast $-20 \mathrm{~g}$, water $-600 \mathrm{ml}$, sugar $-50 \mathrm{~g}$, salt - $20 \mathrm{~g}$, dalda $-25 \mathrm{~g}$, bread improver $10 \mathrm{~g}$ as ingredients. The yeast was added to $100 \mathrm{ml}$ of luke warm water along with a pinch of sugar and set aside for 5 minutes for activation. Salt and sugar were dissolved in the remaining water and filtered through a strainer. The refined wheat flour and bread improver taken as per the recipe were sieved on the working table. Then the flour is made in to dough using water that contained salt and sugar. The activated yeast was added and the dough was kneaded to soft and smooth consistency followed by addition and kneading with fat. The dough was covered under cloth for an hour or till it became double the size at room temperature. Then dough was divided into pieces of $260 \mathrm{~g}$ and moulded to desired shape. Again, the dough was allowed to rise (proofing) in mould for 1 hour to attain maximum possible size. Later, it was baked at $250^{\circ} \mathrm{C}$ temperature for about 25 minutes without disturbance. Baked breads were removed from the oven, cooled, sliced and packed in polyethylene bags for further studies. The refined wheat flour was replaced with banana, sapota and aonla powder in the proportion as detailed in the treatments below and the bread was prepared by following the methodology explained above.

\section{Treatments details}

$\mathrm{T}_{1}-$ Control (standard recipe with refined wheat flour 100\%), $\mathrm{T}_{2}$ $-90 \%$ Refined wheat flour $+10 \%$ Banana powder, $\mathrm{T}_{3}-80 \%$ Refined wheat flour $+20 \%$ Banana powder, $\mathrm{T}_{4}-95 \%$ Refined wheat flour $+5 \%$ aonla powder $\mathrm{T}_{5}-90 \%$ Refined wheat flour $+10 \%$ Aonla powder, $\mathrm{T}_{6}$
- $90 \%$ Refined wheat flour $+10 \%$ Sapota powder, $\mathrm{T}_{7}-80 \%$ Refined wheat flour $+20 \%$ sapota powder.

\section{Physical evaluation of bread}

Colour values $\left(L^{*}, a^{*}, b^{*}\right)$ : The crumb colour of the bread was measured using a Lovibond colour meter (Make: Lovibond RT300, Portable spectrophotometer, The Tintometer Limited, Salisbury, UK) fitted with $8 \mathrm{~mm}$ diameter aperture. The instrument was calibrated using black and white tiles. Samples of breads were directly placed under the aperture of the colour meter. Three measurements were performed for each sample and results were averaged. Colour was expressed in Lovibond units $L^{*}$ (Lightness/darkness), $a^{*}$ (redness/greenness) and $b^{*}$ (yellowness/blueness). Water activity $\left(\mathrm{a}_{\mathrm{w}}\right)$ of bread was measured by using water activity meter (Make: Novasina AG, Switzerland). Water activity of bread was measured by placing 2 slices of bread cut in to quarters in the sample chamber. The observation was directly read in the instrument after it was stabilised. Water absorption and dough rising time for the refined wheat flour or composite flour were determined using Farinograph method. ${ }^{18}$ Dough was made from $260 \mathrm{~g}$ each composite flour with $156 \mathrm{ml}(60 \%$ of flour) of warm water filled inside a burette. The water is allowed to drop gradually into flour in mixing bowl where it formed dough, after which the remaining water in the burette was measured. Dough development time was measured after keeping the dough in mould in warm place for rising. It was observed after 45 minutes and later at one hour for rising.

\section{Chemical evaluation of bread}

Moisture was determined by using moisture balance (Make: P1019319, A \& D Company Limited, Japan). Two gram of bread sample was placed in the sample dish and dried in the electric moisture balance until it automatically showed moisture in percentage after a beep. The instrument indicates the end point of measurement by a beep and gives the constant value for moisture. Protein content of bread was analysed by Biuret method. The protein content in the sample was calculated using a standard graph and expressed in percentage. Crude fiber content in the experimental bread samples was determined by (Acid-Alkali method - Maynard 1970). ${ }^{19}$ The crude fiber content of the sample was expressed as gram per $100 \mathrm{~g}$ or per cent. Gluten content was determined (method 38-10, AACC, 2000). ${ }^{20}$ Carbohydrate content was determined by (AOAC, 1995). ${ }^{21}$ Reducing sugar in samples was estimated as per the Dinitrosalicylic acid method. ${ }^{21}$ The values obtained are expressed as per cent. The per cent non- reducing sugars was obtained by subtracting the value of reducing sugar from that of total sugar. The total sugar content present in the products were estimated by the same method as in case of reducing sugar after inversion of the non- reducing sugar using dilute hydrochloric acid..$^{23}$ The values obtained are expressed as per cent.

\section{Sensory evaluation of bread}

Sensory evaluation of bread was carried out by a panel of 5 semitrained judges immediately after preparation (Figure 1).

\section{Statistical analysis}

The data recorded on the physico-chemical parameters and sensory characteristics were subjected to statistical treatment under completely randomized block design. The level of significance used in ' $F$ ' test was $p=0.05$. Critical difference values were calculated wherever ' $F$ ' test was significant. 


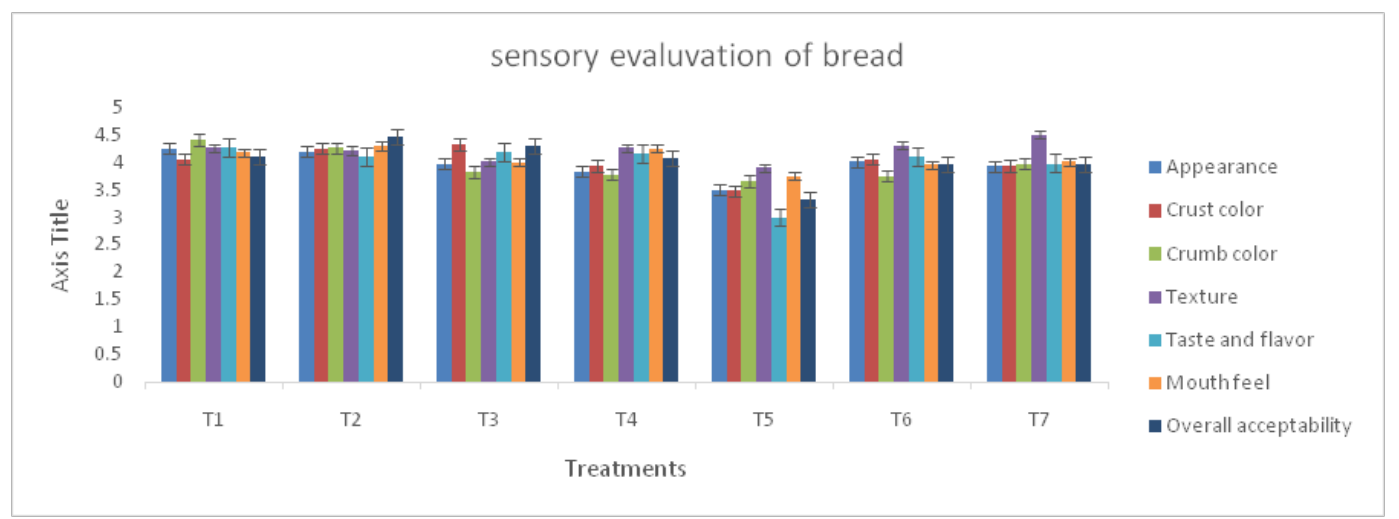

Figure I Effect of fortification with banana, aonla and sapota powders on sensory scores (out of 5) of bread.

\section{Results and discussion}

\section{Physical characteristics' of bread}

The colour of bread varied significantly among the treatments. The treatment $T_{1}$ (100 per cent Refined wheat flour) recorded maximum (69.46) $L^{*}$ value and it was found to be non-significantly differing with $\mathrm{T}_{2}(65.39)$ and $\mathrm{T}_{4}$ (67.01). A minimum value for $L^{*}(45.92)$ was recorded in the bread with 80 per cent wheat flour substituted with 20 per cent of sapota $\left(\mathrm{T}_{7}\right)$. This may be due to the fact that the bread in $\mathrm{T}_{1}$ was prepared from pure refined wheat flour (maida). Bread in which sapota was incorporated (both at $10 \%-L * 54.99$ and at $20 \%-L * 45.92$ ) was found to record minimum $L^{*}$ values. The significantly maximum $a^{*}$ (red) value of 4.44 over rest of the treatments was registered in the bread with 80 per cent wheat flour substituted with 20 per cent of sapota powder $\left(\mathrm{T}_{7}\right)$. The treatment $\left(\mathrm{T}_{5}\right)(90 \%$ wheat flour+ $10 \%$ Aonla powder) showed the maximum $b^{*}$ (yellowness) value of 12.11 . The result indicated that the incorporation of banana, sapota and aonla powders in bread caused darkening effect, reduced the lightness (in case of sapota) and turned them more yellowish (in case of aonla) due to the influence of the pigments present in them. Being slightly reddish grey and more yellowish in colour, compared to control treatment. Earlier studies indicated that darkness in bread might also result from Maillard reaction between reducing sugar and protein due to inclusion of fruits containing sugar. Similar observations were also made by earlier researchers..$^{17,24,25}$ Surprisingly, the same studies also mention that substitution of high fiber ingredient in to bread also darkens the colour of bread (Table 1).

The water activity $\left(\mathrm{a}_{\mathrm{w}}\right)$ of a food describes the lower limit of availability of water for microbial growth. Controlling water activity is important to maintain the chemical stability of foods. Water activity plays an important role in physical properties such as texture and in the shelf life of foods. Measurement of water activity in this study showed no significant differences among the treatments. The range of $\mathrm{a}_{\mathrm{w}}$ in sponge cake, a product akin to bread was stated to be 0.87 to $0.91 .{ }^{\mathrm{w}}$ However, in the present study $\mathrm{a}_{\mathrm{w}}$ observed in all the treatments was in the range that is expected of in bread. Water absorption or water holding capacity of flour is an important characteristic of bread dough. The statistically maximum water absorption in dough (64.per cent) was observed in treatment with 80 per cent refined wheat flour +20 per cent sapota powder $\left(\mathrm{T}_{7}\right)$ and ad it was on par with $\mathrm{T}_{2}, \mathrm{~T}_{3}$ and $\mathrm{T}_{6}$ The significantly minimum water absorption of 57.66 per cent and 58 per cent was found in treatment 10 per cent aonla powder and 90 per cent refined wheat $\left(T_{5}\right)$ and 5 per cent aonla powder and 95 per cent refined wheat powder $\left(\mathrm{T}_{4}\right)$, respectively. Bread flour rich in dietary fiber is able to bind or entrap more water than wheat flour. ${ }^{27}$ The addition of banana and sapota powder to make composite bread flour increased its fiber content leading higher water absorption. The high water absorption of fiber rich powder is attributed to the higher number of hydroxyl groups found in the fiber structure, which tends to allow more water interaction through hydrogen bonding. ${ }^{28}$

This result is in agreement with other workers involving different kinds of fiber and hydrocolloids. ${ }^{11,29}$ Bchir et al. ${ }^{7}$ also reported higher water absorption in date and apple flesh fiber concentrate. Replacement of wheat flour with 10 percent of aonla powder affected the water holding capacity of dough. This may be owed to the acidic nature of the fruit affecting the property of protein or gluten. Significantly maximum dough rising was observed in $T_{1}(100 \%$ Refined wheat flour)However, the minimum dough rising $(4 \mathrm{~cm})$ was recorded in the bread with 90 per cent refined wheat flour +10 per cent aonla powder and it was on par with $\mathrm{T}_{4}$ and $\mathrm{T}_{6}$. It is known that progressive flour replacement with ingredients containing no proteins or gluten could affect dough development characteristics. The results of the present study are in agreement with a study on addition of $10 \%$ spice residues in bread which could affect dough development characteristics. ${ }^{30}$

\section{Chemical evaluation of bread}

Moisture analysis is an important and widely employed determination used in testing of food products. The moisture content of breads in the experiment had a range from 41.00 to 29.16 per cent. A significantly maximum moisture content $(41.00 \%)$ was registered in treatment with 80 per cent refined wheat flour +20 per cent banana and $\left(\mathrm{T}_{3}\right)$ and 80 per cent refined wheat flour with 20 per cent sapota powder $\left(\mathrm{T}_{7}\right)$. However, the minimum moisture content $(29.16 \%)$ was associated with the bread made from 90 per cent refined wheat flour + 10 per cent aonla powder $\left(\mathrm{T}_{5}\right)$ and it differed statistically from all other treatments. This might be attributed to good water holding capacity of banana and sapota powder. Several researches have also reported an increase in moisture content of breads supplemented with non-wheat flours such as pumpkin powder, jackfruit seed flour and green banana powder. $^{27,31,32}$ The significantly maximum protein $(11.31 \%)$ was noticed in $T_{1}(100 \%$ Refined wheat flour) whereas the significantly minimum protein $(8.51 \%)$ was recorded in $\mathrm{T}_{7}(80 \%$ Refined wheat 
flour $+20 \%$ sapota powder). The protein content decreased as the amount of wheat flour replaced by fruit powders increased in this study. It is obviously due to less protein content of fruits than the wheat flour. Similar result of decrease in protein content by addition of bread fruit and bread nut flour in wheat bread has been reported by Malmo et al. ${ }^{33}$ The maximum crude fiber content $(0.82 \%)$ was recorded in $\mathrm{T}_{7}(80 \%$ Refined wheat flour $+20 \%$ Sapota powder) and the minimum crude fiber $(0.27 \%)$ was noticed in treatment $T_{1}(100 \%$ Refined wheat flour bread). Wheat flour is a poor source of fiber because the bran fractions that are high in total dietary fiber contents are removed during the milling process. ${ }^{34}$ Fruits and vegetables are a rich source of fiber. ${ }^{35}$ In the present study, the breads substituted with fruits and vegetables registered higher crude fiber content than the traditional bread recipe $\left(\mathrm{T}_{1}\right)$. This indicates the possible benefit of including horticulture produce in bread in terms of increasing its fiber value (Table 2).

Significantly the highest gluten content (18.33) was recorded in 100 per cent refined wheat flour $\left(\mathrm{T}_{1}\right)$. The least gluten content $(11.66 \%)$ was recorded in treatment $\mathrm{T}_{7}(80 \%$ Refined wheat flour+ $20 \%$ sapota powder) and it was at par with $\mathrm{T}_{3}(12.00 \%)$. This shows that gluten content decreased as the level of substitution increased. It is for this reason that the dough made from 100 per cent wheat flour was more elastic during kneading. On the contrary, this property of dough slightly weakened as the substitution level increased indicating lower level of gluten fraction in composite flours. As expected, the yields of gluten fraction were closely associated with protein contents of flours. In spite of slight reduction in gluten content, these powders (fruits) could be substituted in to wheat flour still maintaining its protein nature for better dough formation. Past research works have also proved that substitution of wheat flour with breadfruit flour makes it possible to have different bread formulations. ${ }^{36-38}$ The maximum carbohydrate content $(54.00 \%)$ was recorded in $\mathrm{T}_{7}$ ( $80 \%$ Refined wheat flour $+20 \%$ sapota powder) whereas minimum carbohydrate content was present in $\mathrm{T}_{1}(47.00 \%)$. This may be attributed to the high content of carbohydrate in banana makes it a quick source of metabolisable energy. Similar result of increase in carbohydrate content by addition of bread fruit and bread nut flour in composite bread has been reported by Malmo et al. ${ }^{33}$ Addition of fruit powders reducing, and total sugar decreased this due to the process of preparing bread involves fermentation and baking as the major steps. The decline in sugar content in the end product is expected to be due to utilization of sugars by yeasts in the fermentation process and chemical changes that occur during baking at higher temperature (250 ${ }^{\circ} \mathrm{C}$ for 25-30minutes). The variation in sugar content with treatments may be attributed to the rate of fermentation and chemical changes as influenced by the incorporated horticultural produce. Variation in the sugar content with control cookies and composite cookies has been reported by Jisha et al..$^{39}$

\section{Sensory evaluation of bread}

Sensory score showed that breads were acceptable at 10 per cent of banana powder. Panellists awarded less scores for bread prepared at 10 per cent of aonla powder. This treatment obtained least score for taste and flavour as well as for overall acceptability due to the unacceptable acidic taste imparted by the aonla (Table 3).

Table I Effect of fortification with banana, aonla and sapota powders on physical characteristics of bread

\begin{tabular}{|c|c|c|c|c|c|c|}
\hline Treatments & $\mathbf{L}^{*}$ & $\mathbf{a}^{*}$ & $\mathbf{b} *$ & aw & Water absorption (\%) & Dough raising $(\mathrm{cm})$ \\
\hline TI & $69.46 \pm 1.32 \mathrm{a}$ & $-0.68 I \pm 0.016 f$ & $7.280 \pm 0.202 c$ & $0.79 \pm 0.07$ & $60.00 \pm 1.15 b$ & $6.500 \pm 1.154 a$ \\
\hline $\mathrm{T} 2$ & $65.38 \pm 1.6 \mathrm{Iab}$ & $-0.238 \pm 0.144 e$ & $6.696 \pm 0.491 \mathrm{c}$ & $0.80 \pm 0.01$ & $62.69 \pm 0.57 a$ & $4.666 \pm 0.333 c$ \\
\hline T3 & $61.56 \pm 0.93 b$ & $0.612 \pm 0.038 d$ & $8.706 \pm 0.332 b$ & $0.82 \pm 0.03$ & $63.85 \pm 0.59 a$ & $4.06 \pm 0.066 c d$ \\
\hline T4 & $67.01 \pm 1.15 a$ & $0.847 \pm 0.187 d$ & $8.426 \pm 0.380 b$ & $0.77 \pm 0.05$ & $58.00 \pm 0.57 b c$ & $5.666 \pm 0.440 d$ \\
\hline T5 & $54.92 \pm 0.84 c$ & $2.731 \pm 0.062 c$ & $12.113 \pm 0.34 a$ & $0.76 \pm 0.06$ & $57.66 \pm 0.66 c$ & $4.000 \pm 0.115 b$ \\
\hline T6 & $54.98 \pm 0.32 c$ & $3.115 \pm 0.149 b$ & $9.123 \pm 0.172 b$ & $0.73 \pm 0.03$ & $63.50 \pm 1.73 a$ & $5.500 \pm 0.577 b$ \\
\hline T7 & $45.92 \pm 3.82 d$ & $4.443 \pm 0.152 a$ & I I. $243 \pm 0.49 a$ & $0.8 I \pm 0.06$ & $64.00 \pm 1.15 a$ & $4.166 \pm 0.16 \mathrm{~cd}$ \\
\hline
\end{tabular}

All values given are means of three determinations. Means in column with different letters are significantly different $(p<0.05)$.

TI -standard recipe with refined wheat flour 100\%)

$\mathrm{T}_{2}-90 \%$ Refined wheat flour $+10 \%$ Banana powder

$\mathrm{T}_{3}-80 \%$ Refined wheat flour $+20 \%$ Banana powder

$\mathrm{T}_{4}-95 \%$ Refined wheat flour $+5 \%$ Aonla powder

$\mathrm{T}_{5}-90 \%$ Refined wheat flour $+10 \%$ Aonla powder

$\mathrm{T}_{6}-90 \%$ Refined wheat flour $+10 \%$ Sapota powder

$\mathrm{T}_{7}-80 \%$ Refined wheat flour $+20 \%$ Sapota powder 
Table 2 Effect of fortification with banana, aonla and sapota powders on chemical parameters of bread

\begin{tabular}{|c|c|c|c|c|c|c|c|c|}
\hline Treatments & $\begin{array}{l}\text { Moisture } \\
\text { (\%) }\end{array}$ & $\begin{array}{l}\text { Protein } \\
(\%)\end{array}$ & $\begin{array}{l}\text { Crude fiber } \\
(\%)\end{array}$ & Gluten (\%) & $\begin{array}{l}\text { Carbohydrate } \\
(\%)\end{array}$ & $\begin{array}{l}\text { Reducing } \\
\text { sugar (\%) }\end{array}$ & $\begin{array}{l}\text { Non reducing } \\
\text { sugars (\%) }\end{array}$ & $\begin{array}{l}\text { Total sugar } \\
\text { (\%) }\end{array}$ \\
\hline $\mathrm{TI}$ & $38.96 \pm 1.15 a$ & || $.3 \mid \pm 0.05 a$ & $0.27 \pm 0.05 \mathrm{~g}$ & $18.33 \pm 0.05 a$ & $47.00 \pm 1.15$ & $4.26 \pm 0.14 a$ & $2.26 \pm 0.05$ & $6.52 \pm 0.20$ \\
\hline $\mathrm{T} 2$ & $39.00 \pm 0.57 a$ & $10.10 \pm 0.05 b$ & $0.3 I \pm 0.06 f$ & $15.33 \pm 0.06 \mathrm{~b}$ & $50.00 \pm 2.00$ & $4.21 \pm 0.37 a$ & $2.10 \pm 0.05$ & $6.15 \pm 0.42$ \\
\hline T3 & $41.00 \pm 0.59 a$ & $9.4 I \pm 0.08 d$ & $0.35 \pm 0.05 e$ & $12.00 \pm 0.05 d$ & $50.77 \pm 1.12$ & $4.01 \pm 0.15 a$ & $2.00 \pm 0.76$ & $6.01 \pm 0.15$ \\
\hline T5 & $29.16 \pm 0.66 c$ & $9.44 \pm 0.05 d$ & $0.6 \mathrm{I} \pm 0.0 \mathrm{lb}$ & $|4.36 \pm 0.0| c$ & $49.33 \pm 1.30$ & $3.66 \pm 0.44 \mathrm{ab}$ & $1.50 \pm 0.57$ & $5.33 \pm 0.44$ \\
\hline $\mathrm{T} 6$ & $38.66 \pm 1.73 a$ & $9.46 \pm 0.05 d$ & $0.52 \pm 0.0 \mathrm{lc}$ & $15.66 \pm 0.05 b$ & $48.66 \pm 5.23$ & $4.3 I \pm 0.22 a$ & $2.10 \pm 0.05$ & $6.33 \pm 0.34$ \\
\hline $\mathrm{T7}$ & $41.00 \pm 1.15 a$ & $8.5 I \pm 0.05 e$ & $0.82 \pm 0.05 a$ & $\mathrm{II} .66 \pm 0.0 \mathrm{Id}$ & $54.00 \pm 5.03$ & $4.15 \pm 0.2 \mathrm{la}$ & $2.01 \pm 0.16$ & $6.25 \pm 0.15$ \\
\hline Cd@5\% & 4.15 & 0.146 & 0.011 & 0.857 & NS & 0.874 & NS & NS \\
\hline
\end{tabular}

All values given are means of three determinations. Means in column with different letters are significantly different $(p<0.05)$.

TI -standard recipe with refined wheat flour $100 \%$ )

$\mathrm{T}_{2}-90 \%$ Refined wheat flour $+10 \%$ Banana powder

$\mathrm{T}_{3}-80 \%$ Refined wheat flour $+20 \%$ Banana powder

$\mathrm{T}_{4}-95 \%$ Refined wheat flour $+5 \%$ Aonla powder

$\mathrm{T}_{5}-90 \%$ Refined wheat flour $+10 \%$ Aonla powder

$\mathrm{T}_{6}-90 \%$ Refined wheat flour $+10 \%$ Sapota powder

$\mathrm{T}_{7}-80 \%$ Refined wheat flour $+20 \%$ Sapota powder

Table 3 Effect of fortification with banana, aonla and sapota powders on sensory scores (out of 5) of bread

\begin{tabular}{|c|c|c|c|c|c|c|c|}
\hline Treatments & Appearance & Crust color & Crumb color & Texture & Taste and flavor & Mouth feel & Overall acceptability \\
\hline $\mathrm{TI}$ & $4.25 \pm 0.25$ & $4.06 \pm 0.15$ & $4.41 \pm 0.22$ & $4.26 \pm 0.14$ & $4.28 \pm 0.0 \mathrm{la}$ & $4.18 \pm 0.22$ & $4.1 I \pm 0.3 \mathrm{Iab}$ \\
\hline $\mathrm{T} 2$ & $4.20 \pm 0.11$ & $4.25 \pm 0.25$ & $4.26 \pm 0.28$ & $4.21 \pm 0.37$ & 4. $10 \pm 0.30 \mathrm{a}$ & $4.30 \pm 0.29$ & $4.47 \pm 0.13 a$ \\
\hline T3 & $3.98 \pm 0.13$ & $4.33 \pm 0.16$ & $3.83 \pm 0.08$ & $4.01 \pm 0.15$ & $4.18 \pm 0.22 a$ & $4.00 \pm 0.28$ & $4.30 \pm-.09 a b$ \\
\hline T4 & $3.83 \pm 0.08$ & $3.93 \pm 0.18$ & $3.78 \pm 0.20$ & $4.26 \pm 0.28$ & $4.16 \pm 0.30 \mathrm{a}$ & $4.25 \pm 0.25$ & $4.07 \pm 0.03 \mathrm{ab}$ \\
\hline T5 & $3.50 \pm 0.28$ & $3.48 \pm 0.24$ & $3.66 \pm 0.08$ & $3.90 \pm 0.37$ & $3.00 \pm 0.57 b$ & $3.75 \pm 0.43$ & $3.32 \pm 0.08 c$ \\
\hline T6 & $4.01 \pm 0.25$ & $4.06 \pm 0.15$ & $3.75 \pm 0.16$ & $4.31 \pm 0.22$ & 4. $10 \pm 0.10 a$ & $3.96 \pm 0.03$ & $3.96 \pm 0.1 \mathrm{lb}$ \\
\hline $\mathrm{T7}$ & $3.93 \pm 0.23$ & $3.93 \pm 0.23$ & $3.98 \pm 0.20$ & $4.5 I \pm 0.21$ & $3.98 \pm 0.13 a$ & $4.01 \pm 0.07$ & $3.97 \pm 0.1 \mathrm{lb}$ \\
\hline
\end{tabular}

All values given are means of three determinations. Means in column with different letters are significantly different $(p<0.05)$.

TI -standard recipe with refined wheat flour 100\%)

$\mathrm{T}_{2}-90 \%$ Refined wheat flour $+10 \%$ Banana powder

$\mathrm{T}_{3}-80 \%$ Refined wheat flour $+20 \%$ Banana powder

$\mathrm{T}_{4}-95 \%$ Refined wheat flour $+5 \%$ Aonla powder

$\mathrm{T}_{5}-90 \%$ Refined wheat flour $+10 \%$ Aonla powder

$\mathrm{T}_{6}-90 \%$ Refined wheat flour $+10 \%$ Sapota powder

$\mathrm{T}_{7}-80 \%$ Refined wheat flour $+20 \%$ Sapota powder 


\section{Acknowledgments}

None.

\section{Conflicts of interest}

The authors declare that there is no conflicts of interest.

\section{References}

1. Sadhu, Chattopadhyay. Introductory fruit crops. 2012;3-6.

2. Morris JN, Marr JW, Clayton DG. Diet and heart: A postscript. Br Med J. 2004;2(6098):1307-1314.

3. Singh A, Singh AK. Optimization of processing variables for the preparation of herb bread using aloe vera gel. J Food Sci Technol. 2009;46(4):335-338.

4. Drozen M, Harrison T. Structure fuction claims for fuctional foods and nutraceuticals. Nutracentical World. 1998;1:18-21.

5. Sadhu, Chattopadhyay. Introductory fruit crops. 2001;6-9.

6. Kadam SS, Salunkhe DK. Vegetable and human nutrition. Handbook of Vegetable science and technology. 1998;163-172.

7. Bchir B, Rabetafika HN, Paquot M, et al. Effect of pear, apple and date fibers from cooked fruit by-products on dough performance and bread quality. Food Bioprocess Technol. 2013.

8. Escalada Pla M, Ana Maria R, Lia Noemi G. Effect of butternut (Cucurbita moschata Duchesne ex Poiret) fibers on bread making quality and staling. Food Bioprocess Techology. 2013;6:828-838.

9. Villela P, Batista AG, Dessimoni-pinto NAV. Nutritional composition of Annona crassiflora pulp and acceptability of bakery products prepared with its flour. Food Science and Technology Campinas. 2013;33(3):417423.

10. Park H, Seib PA, Chung OK. Fortifying bread with a mixture of wheat fiber and psyllium husk fiber plus three antioxidants. Cereal Chem. 19997;74(3):207-211.

11. Abdul-hamid A, Luan YS. Functional properties of dietary fiber from defatted rice bran. Food Chem. 2000;68(1):15-19.

12. Borchani C, Masmoudi M, Besbes S, et al. Effect of date flesh fiber concentrate addition on dough performance and bread quality. Journal of texture studies. 2011;42:300-308.

13. Mahawar M, Singh A, Jalgaonkar K. Utility of apple pomace as a substrate for various products: a review. Food and Bioproducts Processing. 2012;90:597-605.

14. Tsatsaragkou K, Yiannopoulos S, Kontogiorgi A, et al. Mathematical approach of structural and textural properties of gluten free bread enriched with carob flour. Journal of Cereal Science. 2012.

15. Chen H, Rubenthaler GL, Schanus EG. Effect of apple fiber and cellulose on the physical properties of wheat flour. J Food Sci. 1988;53:3004-305.

16. Collar C, Santos E, Rosell CM. Assessment of the rheological profile of fiber-enriched bread doughs by response surface methodology. $J$ food Eng. 2007;78:820-826.

17. Anil M. Using of hazelnut testa as a source of dietary fiber in bread making. Food eng. 2007;80:61-67.

18. AACC. Association of Official analytical chemists, $15^{\text {th }}$ ed, $1990 ; 2: 142-$ 202.

19. Maynard AJ. Methods in Food Analysis Academic Press New York. 1970. p.176.
20. AACC. Approved method of the AACC. $10^{\text {th }}$ ed. America association of cereal chemist. USA. 2000.

21. AOAC. Association of Official analytical chemists, $10^{\text {th }}$ ed. 1995;2:202240.

22. Miller GL. Use of dinitro salicylic acid reagent for determination of reducing sugar. Ann Chern. 1972;31(3):426-428.

23. Anonymous. Official Methods of Analysis. ED. Sidney Williams, Association Official Analytical Virginia. 14 ${ }^{\text {th }}$ ed, 1984. p. 424-462.

24. Sangnark A, Noomhorn A. Chemical, physical and baking properties of dietary fiber prepared from rice straw. Food Research International. 2004;37:66-74.

25. Mohamed A, Jingyuan X, Singh M. Yeast leavened banana bread formulation processing colour and texture analysis. Food Chemistry. 2009; 118:620-626.

26. Nollet ML. Physical characterization and nutrient analysis. Hand book of food analysis, $2^{\text {nd }}$ ed, 2005;(1):39.

27. Noor Aziah AA, HO LH, Noor Shaliana AA, et al. Quality evaluation of steamed wheat bread substituted with green banana flour. Int Food Res J. 2012;19(3):869-876.

28. Rosell CM, Rajas JA, Benedito Barber C. Influence of hydrocolloids on dough rheology and bread quality. Food Hydrocolloids. 15(1):75-81.

29. Gomez M, Ronda F, Blanco CA, et al. Effect of dietary fibre on dough rheology and bread quality. European Food Research and Technology. 2003;216(1):51-56

30. Sosulski FW, Wu KK. High fiber breads containing field pea hulls wheat corn and wild oat brans. Cereal Chemi. 1998;65(3):186-192.

31. Ptitchkin NM, Norokreschonova IV, Piskunova GV, et al. Large enhancements in loaf volume and organoleptic acceptability of wheat bread by small additions of pumpkin powder: possible role of acetylated pectin in stabilizing gas cell structure. Food Hydrocolloids. 1998;12(3):333-337.

32. Tulyathan V, Tananuwong K, Songjinda P, et al. Some physicochemical properties of jackfruit seed flour and starch. Science Asia. 2002;28;37-41.

33. Malmo SA, Eleyinmi AF, Fashakin JB. Chemical composition, rheological properties and bread making potentials of composite flours from breadfruit, breadnut and wheat. African J Food Sci. 2011;5(7):400410 .

34. Sidhu JS, Al-Hooti SN, Al-Saquer J. Effect of adding wheat bran and germ fraction on the chemical composition of high- fiber toast bread. Food Chemistry. 1999;67(4):365-371.

35. Peter IA, John IE. Quality evaluation and cake making potential of sun and oven dried carrot fruit. Int J Biosci. 2012;10(2):19-27.

36. Ragone D. Breadfruit. National Tropical Botanical Garden, Elsevier Science Ltd, Kalaheo, HI, USA. 2003. p. 655-661.

37. Omobuwajo TO. Compositional characteristics and sensory quality of biscuits, prawn crackers and fried chips produced from breadfruit. Innov Food Sci Emerg Technol. 2003;4(2):219-225.

38. Olaoye OA, Onilude AA. Microbiological, proximate analysis and sensory evaluation of baked products from blends of wheat breadfruit flours. Afr J Food Agric Nutr Dev. 2008;8(2):192-203.

39. Jisha S, Padmaja G, Sanjeev MS. Nutritional and textural studies on dietary fiber enriched muffins and biscuits from cassava based composite flours. J Food Qual. 2010;33:79-99. 